\title{
THE EVOLUTION OF HOTELS IN JOHANNESBURG 1890-1948: A CASE OF HISTORICAL URBAN TOURISM
}

\author{
Christian M. ROGERSON* \\ School of Tourism \& Hospitality, College of Business \& Economics, University \\ of Johannesburg, Bunting Road, Johannesburg (South Africa), email: crogerson@uj.ac.za \\ Jayne M. ROGERSON \\ School of Tourism \& Hospitality, College of Business \& Economics, University \\ of Johannesburg, Bunting Road, Johannesburg (South Africa), email: jayner@uj.ac.za
}

\begin{abstract}
Citation: Rogerson, C.M., \& Rogerson J.M. (2018). THE EVOLUTION OF HOTELS IN JOHANNESBURG 1890-1948: A CASE OF HISTORICAL URBAN TOURISM. GeoJournal of Tourism and Geosites, 23(3), 738-747. https://doi.org/10.30892/gtg.23310-324
\end{abstract}

\begin{abstract}
Urban tourism is attracting a growing international scholarship. The aim in this paper is to address the limited focus on historical aspects of urban tourism. Using a range of historical documentary sources this paper analyses the evolution of hotels in Johannesburg from the period of the establishment of the gold mining settlement to the period of the late 1940s. The methodology made use of primary historical data from a range of archival sources. The results reveal certain similar findings to those of other historical research on hotels, most notably the role of city's top tier establishments as foci for the adoption of new technologies and of Johannesburg's leading hotels as nodes of elite sociability. Nevertheless, in terms of interpretation, the most distinctive characteristic of the early hotel economy of Johannesburg was the subordination of the supply of accommodation services to the sale of liquor.
\end{abstract}

Key words: urban tourism, hotels, historical tourism, Johannesburg, South Africa

INTRODUCTION

Debates about urban tourism continue to attract an expanding corpus of international academic scholarship (Ashworth \& Page, 2011; Colomb \& Novy, 2016; Pasquinelli, 2015; Pasquinelli \& Bellini, 2017; Pinkster \& Boterman, 2017; Rogerson \& Rogerson, 2014, 2017). During the 1980s with the occurrence of deindustrialization, accompanying economic recession and widespread distress across many cities of the United States and Western Europe there was a surge of interest in tourism promotion (Law, 1992, 1993). In a context of urban economic crisis and decline policy makers sought out new activities to resuscitate their weakened city economies (Beauregard, 1998; Judd, 2015; Law, 1993). Several cities which previously were centres of production have been re-constructed and re-invented as centres of consumption in particular through the

\footnotetext{
* Corresponding author
} 
building of "an infrastructure of play" in order to support tourism growth (Judd, 2015). By the 1990s Beauregard (1998: 220) could state that in the United States many of the country's large cities "list tourism as one of their most important economic sectors". Arguably, in Europe as well as in North America, tourism "is now a virtually ubiquitous element of urban regeneration policy” (Aksoz \& Bâc, 2012: 8). The promotion of urban tourism in association with the making of post-Fordist cities is not merely confined, however, to North America or Western Europe. Currently, there is a burgeoning urban tourism scholarship that deals with similar issues in cities of Eastern Europe (eg. Cudny, 2011, Dumbrovská \& Fialová, 2014; Iwanicki \& Dłużewska, 2015; Zamfir \& Corbos, 2015), the Middle East (eg. Henderson, 2006, 2014, 2015), Asia (eg. Henderson, 2017; Horita, 2018; Li \& Bihu, 2013; Shi et al., 2017) and sub-Saharan Africa (eg. Rogerson, 2010, 2012, 2014a, 2014b; Rogerson \& Rogerson, 2014; Rogerson \& Visser, 2007, 2011, 2014).

Within the vibrant international scholarship surrounding urban tourism several different strands of writing can be identified. The variegated themes of urban tourism research are critically discussed in recent reviews by Ashworth \& Page (2011), Pasquinelli (2015) and Rogerson \& Rogerson (2017). This said, Murillo et al. (2011: 4) observe that whilst tourists visiting cities represent one of the earliest forms of travel "it was only during the last decades of the twentieth century that many cities became aware of its economic potential and embraced it as a key sector inside their economies". Undoubtedly, city tourism is not a new activity; it has existed and evolved from the earliest days of civilization following the establishment of cities (Karski, 1990). The historical growth of urban centres encouraged people with discretionary means and inclination to tour and to experience cities as focal points of national culture, art, music, literature, architecture and design (Cohen \& Cohen, 2015). In addition, cities as the anchors for economic and political power in national territories became established as destinations for travellers arriving for an array of different purposes (Rogerson \& Rogerson, 2017). Notwithstanding the long tradition of cities as tourism destinations it is apparent that the growing body of international works on urban tourism is dominated overwhelmingly by contemporary thematic issues which often are linked to policy issues. Very little concern is manifest for analysis and excavation of historical aspects of urban tourism. The most notable exception is, perhaps, Cocks (2001) seminal study of the growth of urban tourism in American cities at the turn of the twentieth century and classic works on the Manhattan hotel economy (Baum \& Mezias, 1992).

Among other scholarly contributions addressing dimensions of past urban tourism must be noted investigations on Poland (Klodzinski, 2013), Romania (Badieli et al., 2018), Spain (Urtasan \& Gutiérrez, 2006) as well as South Africa (Bickford-Smith, 2009; Rogerson, 2017). Against this backdrop of limited historical research, the objective in this paper is to investigate one facet of the evolution of tourism in Johannesburg, South Africa's largest city. The paper focuses on the hotel sector as one critical underpinning for tourism expansion in Johannesburg.

The article examines the making of the accommodation infrastructure for tourism in Johannesburg, which is currently South Africa's second most important urban tourism destination (Rogerson \& Rogerson, 2017). More specifically, attention is on the evolution of the early hotel sector which is acknowledged as pivotal for the development of any city as a tourism destination (Cirer-Costa, 2012). As Timothy \& Wall (1995: 65) assert "hotels are the purest and most visible manifestations of tourism in the city". The time period covered by this investigation is from 1890 - shortly after the founding of Johannesburg as a gold mining settlement in 1886 - to 1948 a critical year in South African history as it marks the election to power of the National party which introduced the programme of apartheid policies. Primary data sources used in this study are the 
historical papers collections held both at Johannesburg Public Library (Harold Strange Collection) and the University of the Witwatersrand (William Cullen Historical Papers); tourism business directories, industry press and local newspapers; and, material from the collection of the South African Railways and Harbours.

\section{HOTELS AND HISTORY}

James et al. (2017) point out that it has been almost a century since scholars from various disciplines first became interested in hotels. A distinction is often made between research on hotels which is undertaken from a hospitality management as opposed to studies from a social science perspective (Rogerson, 2013). From a hospitality management viewpoint most existing scholarship concentrates on the business management side of hotels with research questions about marketing (including social media), human resources, facilities, guest satisfaction, reservation and information systems, housekeeping, or catering (Timothy \& Teye, 2009). Beyond hospitality studies the research 'take up' on hotels is much less pronounced. Indeed, although hotels are at the heart of the tourism economy, the actual research on hotels constitutes only a minor theme within broader tourism scholarship (Rogerson, 2013; Timothy \& Teye, 2009). In reviewing extant international scholarship on hotels three critical points must be made. First, that the majority of writings are through a hospitality management lens which leaves a number of knowledge gaps concerning the understanding of the establishment and organization of hotels in relation to the expansion of tourism (Timothy \& Teye, 2009). Second, the largest group of writings on the hotel industry relate to the global North with only a small amount of research investigations on hotels in the global South. The mass of international scholarship on hotels focuses mostly on North America, Western Europe and Asia. In relative terms Latin America and Africa are the most neglected global research locations in relation to hotel research (Rogerson, 2013). Three, as is the case of urban tourism research as a whole, there exist only a limited number of studies that interrogate hotel development from a tourism historical perspective (Cirer-Costa, 2012; Timothy, 2012).

Arguably, following James et al. (2017: 108), it must be acknowledged that "the field of hotel history is in comparative infancy". The key findings of a number of valuable investigations must be noted, however, in order to provide a context for this exploration of early hotel development in South Africa. Historical tourism research has utilised a wide range of methodologies including micro-histories, hotel biographies and a supply and demand approach linked to innovation (Bowie, 2018; McNeill \& McNamara, 2009; Yilmaz et al., 2017). In Europe and North America scholars draw attention to the origins and different trajectories of hotel development in these regions (Bowie, 2016, 2018; James et al., 2017). The importance of inns in the provision of early accommodation services in Europe and North America was challenged from the late eighteenth century. Across Britain and North America 'hotels' superceded inns; in some cases this was the result of inns simply changing their names but, more importantly, it was the outcome of the opening of entirely new establishments as hotels (James et al., 2017). Bowie (2016) alerts us to different pathways for the evolution of hotels in continental Europe as compared to Britain. The major differences are observed, however, in the context of North America where the small inn was replaced by the growth of large hotel establishments. Bowie (2016) stresses the large-scale of hospitality provision in the context of new hotel openings and the ready adoption of new technological advances and management systems in North American hotels. It is emphasized that American hotels pioneered new building technologies and offered new levels of comfort to visitors through "providing elevators, hot and cold running water, chandeliers lit by gas, 'indoor plumbing, steam heat, call bell systems, patent locks' and complex equipment to mechanise kitchens and laundry processes" (Bowie, 2016: 161). 
In Britain inn-keeping in the $18^{\text {th }}$ century offered a rudimentary form of accommodation services which was transformed radically only during the nineteenth century. It is argued that behind this transformation was "the accumulation of a wide range of different innovations which combined to transform the system of hospitality at that time" (Bowie, 2018: 314). Hotels were at the cutting edge for the adoption of new technologies (James et al., 2017). Of critical importance in transforming the character, scale and structure of the hospitality services was the adoption of several sociotechnological innovations. These included the concept of a 'hotel' as a superior form of accommodation for travellers than the inn, the emergence of railway hotels linked to the transport revolution of the $19^{\text {th }}$ century, the adoption of American building processes applying the technology of commercial architecture, and of management practices, most notably the so-termed American plan which "comprised fixed daily tariffs for rooms and meals, the requirement for customers to register and pay for the lodging/food upon arrival and pre-determined times for dining" (Bowie, 2018: 319). The change that occurred as a consequence of these innovations was that the "amateur inn-keeping regime was replaced by more professional hotel management” (Bowie, 2018: 322). In addition, the new order of accommodation services comprised larger, modern hotels, with enhanced facilities, incorporating contemporary technologies, higher quality restaurants and improved levels of professional management (Bowie, 2018). Overall, these major shifts in the character and practice of hotels could be interpreted as manifestations of broader economic and social processes including "the growth of cities, the industrialisation of production and the growth of complex business forms" such that "hotels were sites of modernisation and modernity" (James et al., 2017: 93).

The role of hotels as sites of modernisation was particularly evident in colonial South-East Asia and in Africa. Among others the works of Peleggi (2005) and Goh (2010) highlight that the building of grand luxury hotels such as the Hanoi Metropole, Raffles in Singapore or the Eastern and Oriental in Penang was a vital component of the expansion of transnational capitalism. James et al. (2017: 109) stylize them as "nodes of sociability at the local level and nodes within wider networks of circulation - of people and capital - at the imperial level". The colonial luxury hotel was a principal locus for technological diffusion as well as for the reproduction of metropolitan cultural style (Goh, 2010; Peleggi, 2005). McNeill and McNamara (2012: 151) argue that such hotels "were often early adopters of the latest technologies in terms of building systems (lifts, plumbing, electrical lighting and heating) and communication systems (telegrams and telephones) and showcased the latest architectural styles". In particular, the colonial hotel assumed a special role for local elites who required "an address that could host banquets, society events, trade fairs, and provide suitable accommodation for travelling business people" (McNeill \& McNamara, 2012: 151). Certain characteristics of colonial hotels in South-East Asia find parallels in the record of the early development of hotels in South Africa. Nevertheless, there were also many highly distinctive features of the initial landscape of hotels as revealed by the study of Johannesburg.

\section{EARLY HOTEL DEVELOPMENT IN JOHANNESBURG}

The turbulent period of the 1880s discovery of gold and urbanisation of the Witwatersrand saw extraordinary social, political and economic change in and around the mushrooming mining settlement which, prior to the mineral finds, was merely an area of bare and open veld. The early social and economic history of Johannesburg and the lives of its 'ordinary people' in the rapidly expanding gold mining locale are richly documented in studies by van Onselen (1982). During the hectic years of bursting growth of Johannesburg as a mining settlement as well as the city's early phases of industrialisation 
it was a magnet for new arrivals and business entrepreneurs both from within South Africa and around the world (van Onselen, 1982). The expanding urban population inevitably created a market for accommodation services of various types, most especially of commercial boarding houses. One other dimension of accommodation services was the appearance from the 1890 s of hotel establishments, the growth of which continued into the early decades of the 2oth century (Cole, 1988). Indeed, in many respects, the period from 1890 to 1920 laid the foundations for the Johannesburg hotel economy to satisfy the hospitality requirements of early travellers and tourists to the city.

By 1920 Johannesburg, with an estimated population of 250 000, was the most prosperous settlement in South Africa and, as the chief seat of the gold mining industry, justifiably was styled 'the golden city'. City marketing in the early 1920 s promoted Johannesburg as "the commercial heart of South Africa" and "the most interesting place in a country of fascinations" (Municipality of Johannesburg, 1924: 1317). In addition, with the possibility of attracting visitors it proclaimed "go to Johannesburg for health, business and enjoyment" (Municipality of Johannesburg, 1924: 1317). Official figures to track the expansion in the numbers of hotel establishments in Johannesburg are unavailable. The 1920-21 Illustrated South African Hotel Guide for Travellers and Tourists, however, listed a total of 67 hotels in the city (The Union Publishing Agency, 1921). The vast majority of these establishments were situated in the city's downtown area and immediate surrounding suburbs. With limited automobilities at the time large numbers of hotels in Johannesburg were located in close proximity to railway stations. Indeed, in advertisements, hotels marketed themselves in relation to access to the railway station. For example in the 1936 Illustrated Guide to Hotels in South Africa the Hotel Elgin described itself as Johannesburg's newest hotel "conveniently situated close to Park station", Linton's Hotel was promoted as "next railway station" and Hotel Clarendon was "Opposite the tram Centre...Five minutes from Station" (South African Railways \& Harbours, 1936: 105). Many city hotels also offered the service of porters to meet all trains for potential hotel guests. The two most prestigious hotels in the city also actively marketed to potential tourists but not on the basis of location. The Langham sought to attract visitors with its ' 30 new rooms', 'spacious lounge', 'large banqueting hall', 'well-known dinner' as well as entertainment offerings with an orchestra (The Union Publishing Agency, 1921: 130). This advertising was outshone, however, by that of the Carlton which highlighted that it was a hotel 'de luxe', 'par excellence' and with over 300 bedrooms proclaimed itself as "one of the most luxuriously furnished and equipped in the world" (The Union Publishing Agency, 1921: 122).

A national survey of hotels in South Africa which was conducted by Norval (1936) revealed for 1935 a total of 76 licensed hotels in Johannesburg. Although inevitably between 1920 and 1935 there must have been a churn of establishments - with the closure of certain hotels and openings of others - the broad picture was of a hotel sector in the city that was little changing during this period. One report on Johannesburg hotels for 1935 determined that "the greater proportion of Hotels in Johannesburg have been in existence for the past 30 to 40 years" (Norval, 1936: 249). Examination of the size structure of Johannesburg hotels indicates that the largest share of establishments were significantly small hotels with only between 10 and 24 bedrooms (Table 1). The physical condition of the majority of Johannesburg hotels was a matter of concern and described as "a very unsatisfactory state of affairs" (Norval, 1936: 249). It was argued that the hotel stock by 1935 had seen minimal change since initial construction, and was "without any substantial alteration being made to the buildings apart from minor repairs and renovations from time to time" (Norval, 1936: 249). Of the 76 hotels in 1935 it was recorded that only 18 or 23.7 percent offered their patrons running hot and cold water; this said, even the available bathrooms were on a shared basis with an average of 3.6 bedrooms for each available bathroom (Norval, 1936: 234). 
The Evolution of Hotels in Johannesburg 1890-1948: A Case of Historical Urban Tourism

Table 1. The Size Structure of Hotels in Johannesburg, 1935 (Source: Author based on Norval, 1936)

\begin{tabular}{|c|c|c|}
\hline Size of Hotels & No. & \% Total Hotels \\
\hline 10-24 bedrooms & 29 & 38.2 \\
\hline $25-49$ bedrooms & 28 & 36.8 \\
\hline 50-99 bedrooms & 12 & 15.8 \\
\hline Over 100 bedrooms & 7 & 10.2 \\
\hline TOTAL & 76 & 100 \\
\hline
\end{tabular}

Highly critical reports appeared in local newspapers of the poor conditions in Johannesburg hotels. Comparisons were drawn between the quality standards of shops, theatres, apartment blocks, motor-cars or furniture available in Johannesburg during the 1930s, which were seen as comparable to the best in other parts of the world, and "the relative backwardness of the hotels in Johannesburg" (Rand Daily Mail, 30 October, 1935). Indeed, it was observed in negative fashion that the city's "hotels have to be placed in a class of their own" (Rand Daily Mail, 30 October 1935).

One partial explanation for the generally poor state of city hotels in Johannesburg relates to the "limited demand for high-grade hotel accommodation in South Africa as compared to other countries" (Norval, 1936: 226). For the 1920s and early 1930s international tourism numbers were low for South Africa as a whole as the country was remote from the main currents of tourism traffic and at this time most international arrivals continued to be by ocean steam liners arriving in Cape Town (Saunders \& Barben, 2007; Bickford-Smith, 2009). Accordingly, with "the paucity in the demand for high quality accommodation" the hotel stock of Johannesburg was geared mostly to the less demanding market of the domestic travelling public of South Africa and only "to a very limited extent for those of visitors from overseas" (Norval, 1936: 227). By the 1930s Johannesburg was emerging as a destination for domestic travellers and particularly so at Easter time when the city hosted a major agricultural show as well as several sports events. Although Johannesburg could never match the leisure attractions of South Africa's coastal destinations, including Cape Town, Durban, Port Elizabeth and East London, the city began to identify and market certain leisure attractions. Johannesburg's attractive climate was given a focus and marketed as "a sunshine city built on gold" (Johannesburg Publicity Association, 1931). Another national guide issued in 1932 drew attention to the "unique" sight of the great goldfield, the city's "exhilarating" climate and that "as a holiday resort there is much to commend the city to those in search of sport and pleasure, motoring on good roads, numerous excellent golf links and other interests" (South African Railways \& Harbours, 1932: 85). The city's parks, Zoological Gardens, horse racing and cricket events were identified as special attractions for visitor enjoyment (South African Railways \& Harbours, 1932: 86).

The unsatisfactory state of hotel facilities in Johannesburg could not, however, be explained simply by factors of domestic demand. The most distinctive feature of the Johannesburg hotel economy by the 1930 s was its strong dominance by liquor interests. The origins of the liquor industry's associations with the South African hotel industry can be traced back to the 1890s, the earliest days of Johannesburg, when the so-termed 'tied house' system was introduced into the country by local brewing companies. Under the tied house system a producer or wholesale merchant in liquor could ensure that its tied hotels sell exclusively only particular types of beer or other forms of alcohol (Rogerson, 2011). Licensees were tied to breweries as a result of lease, sub-lease or loan agreements. Starting in the 1890 s this system of tied houses spread and became deeply entrenched in the South African hotel industry such that breweries controlled sales of alcohol in hotels. It was described as follows: a "hotel-keeper is bound to purchase all his beer requirements or the 
bulk thereof from a particular brewer and his wine and spirits from a particular wine and spirit merchant" (Norval, 1936: 251). One consequence of this dominance exercised by liquor companies over the hotel trade was that the sale of alcohol became a more important focus for hotel keepers than the provision of accommodation (Rogerson, 2011; Walker, 1977).

By 1935 it was calculated that 64 percent of Johannesburg hotels were tied to breweries (Norval, 1936: 252). In terms of hotel personnel the implications of the tied houses were instability in terms of the licensees of hotels and the overriding dominance of hotel management by individuals with little focus on the actual supply of accommodation services. Norval (1936: 230) explains that the personnel situation in the hotel sector was characterised by "gross instability and lack of continuity" with widespread evidence "that the hotel industry has become one into which people of diverse origin and profession stray at odd times, hoping to find therein some lucrative source of income”. Correspondingly, it was recorded that the numbers of people who enter the South African hotel industry "in the prime of their life, or who follow their parents in this line of business, intending to make it a career and taking a pride in making an hotel to which visitors will be glad to return must under present conditions be taken as negligible" (Norval, 1936: 230). The control of the hotel trade in South Africa by liquor companies - and especially the country's brewing enterprises - was further consolidated by legislation passed in 1928 which required all licensees of existing bars in urban areas to provide a minimum of 10 bedrooms to retain a liquor licence (Rogerson, 2011). Arguably, it was apparent that "the conditions that the licensees had to meet were largely physical, with little regard being given to the service aspect, and all new licensees carried the obligation to build an 'hotel" (Walker, 1977: 9). The 1928 legislation created a basic change in the character of South African hotels - which persisted until the mid-1960s - that the major focus of the hotel industry was on liquorsales rather than the supply of quality accommodation services. The existence of this legislation provides a basis for understanding the high proportion of small hotels in Johannesburg, especially in the city centre, which offer the "bare ten rooms" as required by the legislation in order simply to secure the license for liquor sales. The quality of hotel buildings and provision of accommodation was of minimal concern as most of the stock of early Johannesburg hotels by the mid-1930s were nothing but thinly disguised bars (Rogerson, 2013). A decade later at the close of the Second World War the essential character and problems of the hotel industry in Johannesburg were little changed. The precarious economic situation of most hotels in terms of reliance on the bar for profits had been exacerbated by the introduction in 1939 of controls on price increases that hotels could enact. As Walker (1977: 10) argues for well-run hotels tariffs for accommodation services "were fixed too low to yield a return attractive enough in relation to the effort required". With no control on the tied-house system or amendment of the legislation that subordinated the hotel industry to liquor interests, hotel accommodation standards were continually under fire. The situation for the majority of Johannesburg hotels refracted the national situation of being "far from being ideal and there was scope for much improvement" (Rand Daily Mail, 1 March 1944). Newspaper reports in 1944 recorded that hotel-keepers were viewed as "a suspicious and even predatory character" (Rand Daily Mail, 27 October 1944). One consequence of the controls on accommodation tariffs was to bolster poor management of the hotel industry as a whole (Crocker, 1950; Walker, 1977). Overall, the mass of the liquor-dominated hotel establishments in Johannesburg continued to offer unsatisfactory standards of accommodation as well as poor "standards of service, civility, cleanliness and cuisine" (Maggs, 1949: 17).

The major exceptions to this depressing picture of Johannesburg hotels were a small group of the city's most fashionable hotels, some of which could be compared in quality and function with the classic colonial hotels of South East Asia (Rogerson, 2018). 
Cole (1988) reports that the Grand National, which opened in 1890, was Johannesburg's most fashionable establishment of the time being advertised as in "the healthiest part of town with "three splendid drawing-rooms facing the three principal streets, ladies sitting rooms as well as hot and cold baths" (Cole, 1988: 7). This hotel was a feature of Johannesburg social scene until 1939 when the downtown site was so valuable that the hotel was demolished in order to make way for shops. The offerings of Heath's, North Western Hotel, and the Grand Central Hotel, with a dining room "adorned by handsome mirrors" also placed these hotels for a short period amongst the preferred destinations of Johannesburg elites. Other upper echelon hotels enjoyed a longer history. For example, the Langham Hotel, established in 1905 (and surviving until 1972) was described by Benjamin (1979: 23), as representing "something special in the social fabric of Johannesburg" as the hotel "had grace, charm and solid old-world comfort". It was a rendezvous for rich mining magnates, local and international celebrities, including royalty, and considered as "expensive, discreet, smaller and less flashy than the Carlton which was opened not long afterwards". Above all, the Carlton Hotel was Johannesburg's showcase and most distinguished hotel (Rogerson, 2018). Rosenthal (1972: 32) writes of Johannesburg's "great hotel" that taste "is the keynote of the decorative scheme, as comfort is the motive of the building's design". He continues: "From the lowest basement to the topmost story there is visible no single garish feature, no architectural effect with which the most hyper-critical visitor could possibly find fault”. Overall, the hotel was endowed with plush interior appointments, the latest innovative technologies, including in the basement a "full-scale Turkish bath and massage establishment, with a marble swimming pool" (Benjamin, 1979: 10). As documented by both Rosenthal (1972) and Hughes (1983) for many years the Carlton remained the most prestigious address in Johannesburg, a central meeting place for important events and for gala social functions in a manner that exhibits certain parallels with those described for colonial imperial hotels.

\section{CONCLUSION}

The topic of urban tourism continues to generate an impressive and expanding scholarship (Colomb \& Novy, 2016; Pasquinelli, 2015; Pasquinelli \& Bellini, 2017). As argued earlier, the bulk of writings is contemporary in focus and mainly concentrates on developments around urban tourism in the global North. This article offers a modest contribution to examining historical aspects of urban tourism in the less well researched cities of the global South by interpreting the character of the early hotel industry of Johannesburg, South Africa's largest centre. The analysis discloses certain similar findings to those of other investigations, most notably the role of city's top tier establishments as foci for the adoption of new technologies and of the leading hotels as nodes of elite sociability. This said, the most distinctive characteristic of the early hotel economy of Johannesburg was the dominance of liquor interests through the tied house system and the legislative requirement that linked access and retention of a liquor licence to the provision of ten rooms for basic accommodation. The modernization of the Johannesburg hotel industry and a refocusing on accommodation provision rather than liquor selling was delayed until the mid-1960s (see Rogerson 2011).

\section{REFERENCES}

Aksoz, O.E., Bâc, D.P. (2012). The importance of urban tourism for hotel marketing policies: The case of Eskişehir. GeoJournal of Tourism and Geosites, vol.9, no 1, p. 7-16.

Ashworth, G.J., Page, S. (2011). Urban tourism research: Recent progress and current paradoxes. Tourism Management, vol. 32, no 1, p. 1-15. 
Baum, J.A.C. Mezias, S.J. (1992). Localized competition and organizational failure in the Manhattan hotel industry, 1898-1990. Administrative Science Quarterly, vol. 37, p. 580- 604.

Badieli, F., Ilies, D.C., Castaldini, D. (2018). A tale of a city, through its urban landscape and cultural heritage in the heart of Europe: The case study of Oradea City (Romania). GeoJournal of Tourism and Geosites, vol. 21, no. 1, p. 88-102.

Beauregard, R.A. (1998). Tourism and economic development policy in US urban areas. In: Ioannides D., Debbage K.G. (eds). The Economic Geography of the Tourist Industry: A Supply-Side Analysis. Routledge, London, p. 220-234.

Benjamin, A. (1979). Lost Johannesburg. Macmillan, Johannesburg.

Bickford-Smith, V. (2009). Creating a city of the tourist imagination: The case of Cape Town, 'The Fairest Cape of all'. Urban Studies, vol, 46, no. 9, p. 1763-1785.

Bowie, D. (2016). Pure diffusion?: The great English hotel charges debate in The Times, 1853. Business History $58(2), 159-178$.

Bowie, D. (2018), Innovation and 19th century hotel industry evolution. Tourism Management, vol. 64, p. 314-323.

Cirer-Costa, J.C. (2012). The beginnings of tourism in Majorca 1937-1914. Annals of Tourism Research, vol. 39, no. 4, p. 1779-1796.

Cocks, C. (2001). Doing the Town: The Rise of Urban Tourism in the United States, 1850-1915. University of California Press, Berkeley.

Cohen, E., Cohen, S.A. (2015). A mobilities approach to tourism from emerging world regions, Current Issues in Tourism, vol. 18, no. 1, p. 11-43.

Cole, M. (1988). Room In the Inn: The Story of Johannesburg Hotels, Poplar Press, Johannesburg.

Colomb, C., Novy, J. (Eds.) (2016). Protest and Resistance in the Tourist City. Routledge, Abingdon.

Crocker, H.J. (1950). What's wrong with the hotel industry? Commercial Opinion, vol. 28 (December), p. 309 and 325.

Cudny, W. (2011). Film festivals in Lodz as a main component of urban cultural tourism. Bulletin of Geography: Socio-Economic Series, vol. 15, p. 131-141.

Dumbrovská, V., Fialová, D. (2014). Tourist intensity in capital cities in Central Europe: Comparative analysis of tourism in Prague, Vienna and Budapest. Czech Journal of Tourism, vol. 1, p. 5-26.

Goh, D.P.S. (2010). Capital and the transfiguring monumentality of Raffles Hotel. Mobilities, vol. 5, no. 2, p. 177-195.

Henderson, J. (2006). Tourism in Dubai: Overcoming barriers to destination development. International Journal of Tourism Research, vol. 8, p. 87-99.

Henderson, J. (2014). Global Gulf cities and tourism: A review of Abu Dhabi, Doha and Dubai. Tourism Recreation Research, vol. 39. No. 1, p. 107-114.

Henderson, J. (2015). The development of tourist destinations in the Gulf: Oman and Qatar compared. Tourism Planning and Development, vol.12, no. 3, p. 350-361.

Henderson, J. (2017). Global cities, Tokyo, urban tourism. International Journal of Tourism Cities, vol. 3 no. 2, p. 143-157.

Horita, Y. (2018). Urban development and tourism. in Japanese cities, vol.15, no. 1, p.26-39.

Hughes, L. (1983). Johannesburg: The Cosmopolitan City. Delta, Johannesburg.

Iwanicki, G., Dłużewska, A. (2015). Potential of city break clubbing tourism in Wroclaw. Bulletin of Geography: Socio-Economic Series, vol. 28, p. 77-89.

James, K.J., Sandoval-Strausz, A.K., Maudlin, D., Peleggi, M., Humair, C., Berger, M.W. (2017). The hotel in history: Evolving perspectives. Journal of Tourism History, vol. 9, no. 1, p. 92-111.

Johannesburg Publicity Association (1931). Johannesburg: A Sunshine City Built on Gold, Johannesburg Publicity Association and South African Railways and Harbours Administration, Johannesburg.

Judd, J.R. (ed.) (2015). The Infrastructure of Play: Building The Tourist City, Routledge, London.

Karski, A. (1990). Urban tourism - a key to urban regeneration,. The Planner, vol.76, no. 13, p. 15-17.

Klodzinski, J. (2013). Tourism in Gdynia to second world war. GeoJournal of Tourism and Geosites, vol. 13, no. 2, p.111-119.

Law, C.M. (1992). Urban tourism and its contribution to economic regeneration. Urban Studies, vol. 29, p. 599-618.

Law, C. M. (1993). Urban tourism: Attracting visitors to large cities. Mansell, London.

Li, M., Bihu, W. (2013). Urban tourism in China, Routledge, London.

Maggs, E.O.C. (1949). What we expect our hotels to give the tourist. The Outspan, vol. 46, p.7, 19 and 81.

McNeill, D., McNamara, K. (2009). Hotels as civic landmarks, hotels as assets: The case of Sydney's Hilton. Australian Geographer, vol. 40, no. 3, p. 369-386.

McNeill, D., McNamara, K. (2012). The life and death of great hotels: A building biography of Sydney's 'The Australia'. Transactions of the Institute of British Geographers, vol. 37, p. 149-163.

Municipality of Johannesburg (1924). Johannesburg: Our Empire's great gold centre, South African Railways and Harbours Magazine, December, p. 1317.

Murillo, J., Vaya, E., Romani, J., Surinach, J. (2011). How important to a city are tourists and daytrippers?: The economic impact of tourism on the city of Barcelona, University of Barcelona, Research Institute of Applied Economics, Barcelona.

Norval, A.J. (1936). The Tourist Industry: A National and International Survey, Sir Isaac Pitman, London.

Pasquinelli, C. (2015). Urban tourism (s): Is there a case for a paradigm shift? L' Aquila, Gran Sasso Science Institute, Cities Research Unit Working Papers No. 14.

Pasquinelli, C., Bellini, N. (2017). Global context, policies and practices in urban tourism: An Introduction. In: Bellini, N., Pasquinelli, S., (eds.) Tourism in the city: Towards an integrative agenda on urban tourism, Springer, Dordrecht, p. 1-25. 
Peleggi, M. (2005). Consuming colonial nostalgia: The monumentalism of historic hotels in urban South-East Asia. Asia-Pacific Viewpoint, vol. 46, p. 255-265.

Pinkster, F.M., Boterman, W.R. (2017). When the spell is broken: Gentrification, urban tourism and privileged discontent in the Amsterdam canal district. Cultural Geographies, vol.24, no. 3, p.457-472.

Rand Daily Mail (Johannesburg). 30 October, 1935; 1 March, 1944; 27 October, 1944

Rogerson, C.M. (2011). From liquor to leisure: The changing South African hotel industry 1928-1968, Urban Forum, vol. 22, p. 379-394.

Rogerson, C.M., Rogerson, J.M. (2014). Urban tourism destinations in South Africa: divergent trajectories 20012012. Urbani izziv, vol. 25 (Supplement), p. S189-S203.

Rogerson, C.M., Rogerson, J.M. (2017). City tourism in South Africa: Diversity and change. Tourism Review International, vol. 21, no. 2, p. 193-211.

Rogerson, C.M., Visser, G. (Eds.) (2007). Urban tourism in the developing world: The South African experience. New Brunswick, NJ.: Transaction Press.

Rogerson, C.M., Visser, G. (2011). Rethinking South African urban tourism research. Tourism Review International, 15, 77-90.

Rogerson, C.M., Visser, G. (2014). A decade of progress in African urban tourism scholarship. Urban Forum, vol. 25 , no. 4 , p. $407-418$.

Rogerson, J.M. (2010). The boutique hotel industry in South Africa: Definition, scope and organization. Urban Forum, vol. 21, p. 425-439.

Rogerson, J.M. (2012). The changing location of hotels in South Africa's coastal cities. Urban Forum, vol. 23, p. 73-91.

Rogerson, J.M. (2013). Size matters in the African hotel industry: The case of South Africa. African Journal for Physical, Health Education. Recreation and Dance, vol. 19 (Supplement 2), p. 217-233.

Rogerson, J.M. (2014a). Hotel location in Africa's world class city: The case of Johannesburg, South Africa. Bulletin of Geography: Socio-Economic Series, vol.25, p. 181-196.

Rogerson, J.M. (2014b). Changing hotel location patterns in Ekurhuleni, South Africa's industrial workshop. Urbani izziv, vol. 25 (Supplement), p. S81-S95.

Rogerson, J.M. (2017). Kicking sand in the face of apartheid: Segregated beaches in South Africa. Bulletin of Geography: Socio-Economic Series, vol. 35, p. 93-109.

Rogerson, J. M. (2018). The early development of hotels in Johannesburg ca 1928-1963. African Journal of Hospitality Tourism and Leisure, vol. 7, no4, p. 1-16.

Rosenthal, E. (1972). Meet me at the Carlton: The Story of Johannesburg's Old Carlton Hotel. H.B. Timmins, Cape Town.

Saunders, C., Barben, T. (2007). The history of tourism. In George. R, (ed.), Managing Tourism in South Africa, Oxford University Press, Cape Town, p. 25-31.

Shi, B., Zhao, J., Chen, P.J. (2017). Exploring urban tourism crowding in Shanghai via crowdsourcing geospatial data. Current Issues in Tourism, vol. 20, no.11, p. 1186-1209.

South African Railways and Harbours (1932). Illustrated Guide to Hotels and Boarding Houses, 1932, Government Printer, Pretoria.

South African Railways and Harbours (1936). Illustrated Guide to Hotels and Boarding Houses, 1936, Government Printer, Pretoria.

Timothy, D.J. (2012). Historical geographies of tourism. In. Wilson, J. (ed.), The Routledge Handbook of Tourism Geographie, Routledge, London, p. 157- 162.

Timothy, D. J., Teye, V. B. (2009). Tourism and the lodging sector, Butterworth-Heinemann, London.

Timothy, D.J., Wall, G., (1995). Tourist accommodation in an Asian historic city. Journal of Tourism Studies, vol. 6, p. 63-73.

The Union Publishing Agency (1921). The Illustrated South African Hotel Guide for Travellers and Tourists, Cape Times Limited, Cape Town.

The Union Publishing Agency (1924). The Illustrated Guide to South Africa 1924, Cape Times, Cape Town.

Urtasun, A., Gutiérrez, I. (2006). Hotel location in tourism cities: Madrid 1936-1998. Annals of Tourism Research, vol. 33, p. 382-402.

van Onselen, C. (1982). Studies in the Social and Economic History of the Witwatersrand 1886-1914, 2 vols, Ravan, Johannesburg.

Walker, G.S. (1977). The history of the South African hotel industry with special reference to the role of the Hotel Board. Unpublished dissertation, National Diploma in Hotel Management, The Hotel School, Johannesburg.

Yilmaz, A., Yetgin, D., Kozak, N. (2017). A hotel in Anatolia in the last period of the Ottoman Empire: Hotel Tadia (1892-1922). Tourism Management Perspectives, http://dx.doi.org/10.106/j.tmp.2017.08.002

Zamfir, A., Corbos, R. (2015). Toward sustainable tourism development in urban areas: Case study on Bucharest as tourist destination. Sustainability, vol. 7, no. 9, p. 12709-12722.

Submitted:

01.10.2018
Revised:

26.10.2018
Accepted and published online 30.10 .2018 